\title{
Performance and morphological response of the hybrid poplar DN-74 (Populus deltoides $\times$ nigra) under different spacings on a 4-year rotation
}

\author{
Guy R. Larocque \\ Natural Resources Canada, Canadian Forest Service, Laurentian Forestry Centre, \\ 1055 du P.E.P.S., P.O. Box 3800, Sainte-Foy, Quebec G1V 4C7, Canada
}

(Received 8 April 1998; accepted 15 December 1998)

\begin{abstract}
The effect of competition on the performance and morphological response of the hybrid poplar DN-74 (Populus deltoides $\times$ nigra) was examined by varying stand density from 4444 stems ha $^{-1}$ to 40000 stems ha ${ }^{-1}$. The root collar diameter growth of individual trees was inversely related to the intensity of competition, as there was nearly a two-fold decrease in root collar diameter from the largest to the closest density after only four growing seasons. Crown width, crown ratio, leaf biomass and leaf area decreased significantly with an increase in density. However, crown shape ratio, leaf area projection and leaf area ratio did not vary significantly with stand density, and specific leaf area decreased with the degree of crown closure and crown depth, which indicated that this hybrid shows a high degree of plasticity in response to competition. Nutrient contents of foliage and stems did not vary much with the intensity of competition. (C Inra/Elsevier, Paris.)
\end{abstract}

relative growth rate / leaf area / specific leaf area / competition / short rotation forestry

Résumé - Performance et réponse morphologique du peuplier hybride DN-74 (Populus deltoides $\times$ nigra) sous différents espacements pour une rotation de quatre ans. L'effet de la compétition sur la performance et la réponse morphologique du peuplier hybride DN-74 (Populus deltoides $\times$ nigra) a été examiné en faisant varier la densité de 4444 tiges ha ${ }^{-1}$ à 40000 tiges ha $^{-1}$. La croissance en diamètre au niveau du collet était inversement reliée à l'intensité de la compétition : le diamètre au niveau du collet a diminué de moitié de la plus faible densité à la plus élevée après seulement quatre saisons de croissance. La largeur de la cime, le rapport de la longueur de la cime sur la hauteur de la tige, la biomasse foliaire et la surface foliaire ont diminué de façon significative avec un accroissement de la densité. Cependant, le rapport de la largeur de la cime sur la longueur de la cime, la surface foliaire projetée et le rapport de la surface foliaire sur la biomasse foliaire et des tiges n'ont pas varié de façon significative avec la densité, et la surface foliaire spécifique a diminué avec le degré de fermeture du couvert et la profondeur dans le couvert, ce qui indique que cet hybride se caractérise par un degré élevé de plasticité quand il est soumis à la compétition. Les contenus en éléments nutritifs du feuillage et des tiges n’ont pas varié de façon appréciable avec l'intensité de la compétition. (C Inra/Elsevier, Paris.)

taux relatif de croissance / surface foliaire / surface foliaire spécifique / compétition / foresterie à courte révolution

\section{Introduction}

The introduction of various hybrid poplar clones into North America for intensive production of biomass on short rotation generated numerous studies which aimed at comparing the productivity of several hybrids $[5,9$, 46] and evaluating the effect of stand density and cultural treatments such as fertilization, sludge application or

glarocque@cfl.forestry.ca 
weed control $[7,8,16,21-23]$. The main contribution of these types of studies has consisted in providing sound guidelines based on empirical knowledge for the management of poplar plantations. However, there is still little information concerning the amplitude of above- and below-ground competition. Moreover, the extent to which acclimation to competitive stress takes place in hybrid poplar remains unknown. These issues must be addressed with experimental data based on the comparison of trees subject to different intensities of competition to ensure that biomass productivity is not affected by excessive mortality or under-utilization of growing space and site resources. This information is crucial in guiding foresters to select an optimal spacing and rotation period and to assess the necessity to apply expensive cultural treatments such as fertilization or irrigation in order to increase biomass production per unit area.

Plants may respond to the intensification of competition for site resources by increasing uptake rate, reducing losses or improving the efficiency of their internal morphological and physiological apparatus to produce new biomass [18]. For instance, changes in morphological characteristics such as the number of palisadic parenchyma layers or chloroplasts, stomatal density and size, which indicate acclimation to variation in light conditions $[1,15,17]$, may occur when the increase in competitive stress results in substantial changes in the amount of solar radiation intercepted by the canopy. These types of change in morphological characteristics, which are related to changes in physiological characteristics such as light compensation point, are probably important when competition takes place in hybrid poplar stands because fast-growing species are usually characterized by a high degree of plasticity [31], and greater rates of nutrient uptake, accumulation and turnover than most temperate species [2].

The objectives of the present study were to evaluate the performance of the hybrid poplar DN-74 (Populus deltoides $\times$ nigra) under competition in a 4-year rotation and to determine how it responds to competitive stress. This clone was selected for the present study because it was planted quite extensively in eastern Canada [39]. The extent to which crowns and foliage responded in terms of space occupancy, efficiency to occupy growing space and modifications in morphological characteristics and the effect on tree nutrition were examined. The following hypotheses were tested. As the intensity of competitive stress increases, crowns acclimate greatly to reduced growing space. There is strong interaction between leaf nutrition and leaf acclimation. However, despite acclimation, the efficiency of crowns to occupy their growing space is negatively affected.

\section{Materials and methods}

\subsection{Experimental design and measurements}

The experiment took place in the nursery of the Petawawa National Forestry Institute (latitude $46^{\circ} 00^{\prime} \mathrm{N}$, longitude $76^{\circ} 26^{\prime} \mathrm{W}$ ). Cuttings measuring $25 \mathrm{~cm}$ provided by the Ontario Ministry of Natural Resources were planted in three square spacings in June 1990: 0.5, 1.0 and 1.5 $\mathrm{m}$. The experimental design consisted of a Latin square with two blocks. Eighteen plots measuring $6 \mathrm{~m} \times 6 \mathrm{~m}$ separated by a distance of $2 \mathrm{~m}$ were laid out on the field. Thus, each spacing was replicated six times. The edge row on each side of every sample plot was considered as a buffer zone. Grass vegetation was hand-removed regularly to eliminate the effect of interspecific competition. As more than one stem emerged from individual cuttings, every stem was identified with a numbered tag to ensure that the growth of each individual stem would be monitored. For most of the cuttings, the first stem that emerged was characterized by far superior growth than those that appeared later. For this reason, both groups were analysed separately. Thus, the term main stem will be used to designate the stems that appeared first on a cutting while the term secondary stem will designate those that appeared later.

Root collar diameter (RCD) $( \pm 1 \mathrm{~mm})$ and total height $( \pm 1 \mathrm{~cm})$ of each stem originating from cuttings were measured at the end of each growing season. In October 1993, 102 trees (main and secondary stems) were selected in each sample plot for detailed biomass and nutrient measurements. The number of trees harvested in every sample plot differed with spacing: 10,4 and 3 within the $0.5,1.0$ and $1.5 \mathrm{~m}$ spacing, respectively. A stratified random sampling procedure was used for each plot to ensure that small and large trees would be adequately represented. First, all the trees were grouped into diameter classes, and then trees were selected at random within each diameter class. Before trees were harvested, RCD, height and maximum crown width and length $( \pm 1 \mathrm{~cm})$ were measured. Then, crowns were separated into three equal sections in height and harvested separately. In the remainder of the text, sections 1,2 and 3 will refer to the bottom, middle and top sections of the crown, respectively. For all the foliage in every crown section, leaf area was measured with a LI-COR area meter, model LI3100 [32], with a resolution of $\pm 1 \mathrm{~mm}^{2}$, and leaf biomass was determined after drying the material in an oven at $70^{\circ} \mathrm{C}$ until no change in mass was detected.

All the basic measures specified above were used to derive measures of performance or growth efficiency $[24,25]$ : 


$$
\mathrm{RGR}=\frac{\left(\ln \mathrm{W}_{2}-\ln \mathrm{W}_{1}\right)}{\left(\mathrm{T}_{2}-\mathrm{T}_{1}\right)}
$$

Relative growth rate (RGR) is a measure of growth efficiency that estimates the capacity of trees to produce biomass $[14,28] . \mathrm{W}_{2}$ and $\mathrm{W}_{1}$ represent $\mathrm{RCD}$ or height at ages $T_{2}$ and $T_{1}$, respectively.

While an absolute measure such as crown width provides an evaluation of the effect of competition on aerial space occupancy, relative measures can be derived to evaluate the efficiency of crowns to occupy their growing space:

$$
\mathrm{CR}=\frac{\text { Crown length }}{\text { Stem height }}
$$

Crown ratio $(\mathrm{CR})$ is an indicator of the photosynthetic capacity of a tree [45] and, thus, constitutes a measure of its vigor.

$$
\mathrm{CSR}=\frac{\text { Crown width }}{\text { Crown length }}
$$

Crown shape ratio (CSR) evaluates the ability of crowns to intercept solar radiation $[30,41,51]$. The lower the ratio, the more efficiently crowns intercept solar radiation within dense stands.

$$
\mathrm{LAP}=\frac{\text { Leaf area }}{\text { Crown projection }}
$$

Leaf area projection (LAP) estimates the amount of leaf cover over the horizontal area occupied by individual crowns.

The last three ratios constitute measures of production efficiency, as they estimate the capacity of crowns to intercept solar radiation or occupy their aerial growing space in different conditions of stand density.

Two relative measures were derived to examine the effect of competition on morphological characteristics of crowns and foliage:

$$
\mathrm{LAR}=\frac{\text { Leaf area }}{\text { Stem and leaf biomass }}
$$

Leaf area ratio (LAR) estimates the proportion of photosynthesizing biomass relative to respiring biomass, and also depends on the anatomy and chemical composition of foliage [31].

$$
\text { SLA }=\frac{\text { Leaf area }}{\text { Leaf biomass }}
$$

Specific leaf area (SLA) is highly sensitive to light environment [27, 47], and nutrient contents [10,31, 34].

\subsection{Plant and soil nutrient determinations}

Nutrient concentrations for stem and foliage within each crown section were determined for the main stems at the end of the fourth growing season in October 1993. For the foliage in each crown section and the stem of every tree, all the biomass was thoroughly mixed and a subsample was taken and ground for laboratory analyses. Nitrogen content was determined with a NA-2000 dry combustion $\mathrm{N}$-analyzer [13]. The first step in determining the contents in $\mathrm{P}, \mathrm{K}, \mathrm{Mg}$ and $\mathrm{Ca}$ consisted in applying the dry ashing procedure of Kalra and Maynard [26]. Then, an Ultrospec II spectrophotometer $[26,33]$ was used for $\mathrm{P}$ and an atomic absorption spectrophotometer was used for $\mathrm{K}, \mathrm{Ca}$ and $\mathrm{Mg}$ [49].

Within each plot, soil samples were collected in October 1993 with a large AMS soil corer between 0 and $10 \mathrm{~cm}, 10$ and $20 \mathrm{~cm}$, and 20 and $30 \mathrm{~cm}$ at four locations positioned along the diagonal of the plots and $1 \mathrm{~m}$ from the center. The samples were dried, weighed and sieved to $2 \mathrm{~mm}$. Then bulk density and $\mathrm{pH}(1: 2.5$ soil:0.01 M $\mathrm{CaCl}_{2}$ ) were measured. Nitrogen content was determined by the Kjeldahl procedure [26], and $\mathrm{P}, \mathrm{K}, \mathrm{Mg}$ and $\mathrm{Ca}$ contents by Mehlich extraction combined with an Ultrospec II spectrophotometer [26, 33, 37].

\subsection{Statistical analysis}

As the growth of individual trees was measured repeatedly, a multivariate approach with repeated measures was used to analyze cumulative growth and RGR for RCD and height using the GLM procedure in SAS [44].

$$
y_{i j k l n}=\mu+\rho_{i}+\alpha_{j(i)}+\beta_{k(i)}+\tau_{1}+\gamma_{n}+a_{i k}+e_{i j k l}
$$

where $y_{i j \mathrm{jln}}$ is the dependent variable, $\mu$ the overall mean effect, $\rho_{\mathrm{i}}$ the effect of the Latin square, $\alpha_{\mathrm{j}(\mathrm{i})}$ the slope effect within a block, $\beta_{k(i)}$ the section effect within the block, $\tau_{1}$ the spacing effect, $\gamma_{n}$ the age effect (repeated measurement), $a_{i k}$ a random effect related to groups of three plots within each block, and $\mathrm{e}_{\mathrm{ijk} \mathrm{k}}$ the residual error. Greek characters represent fixed effects and Roman characters, random effects. Subscripts refer to individual observations within each effect. Orthogonal contrasts were computed when the age $\times$ spacing effect was significant in order to compare the spacings over time. Contrast I was defined to compare the $0.5 \mathrm{~m}$ spacing with the $1.0 \mathrm{~m}$ and $1.5 \mathrm{~m}$ spacings $(2,-1,-1)$ and contrast II to compare the $1.0 \mathrm{~m}$ spacing with the $1.5 \mathrm{~m}$ spacing $(0,-1,-1)$. As there were repeated measurements, the significance test for a particular growing season determines if the difference between treatments 
obtained differs from the difference in the last growing season [44]. The same ANOVA model and coefficients of orthogonal contrasts were used to compare growth and crown parameters measured at harvesting and nutrient content data, except that the repeated measurement component $\left(\gamma_{n}\right)$ was excluded.

Linear regression analysis of SLA as a function of nutrient concentration was undertaken to compare the slope of the relationship among spacings. The degree of the slope provides a measure of nutrient use efficiency: the steeper the slope, the more efficiently nutrients are used to build up leaf material. Differences in slope among spacings would indicate strong interaction between leaf nutrition and leaf acclimation under different intensities of competition.

\section{Results}

\subsection{Soil conditions}

Bulk density and $\mathrm{pH}$ at three depths did not differ significantly among the spacings (table I). For the whole site, average values were $1.25,1.50$ and $1.57 \mathrm{~g} \mathrm{~cm}^{-3}$, and 4.66, 4.61 and 4.91 for bulk density, and $\mathrm{pH}$ between 0 and $10 \mathrm{~cm}, 10$ and $20 \mathrm{~cm}$, and 20 and $30 \mathrm{~cm}$, respectively. Also, no significant differences were found for nutrient concentrations (table I). Average values for the whole site were $0.79 \mathrm{mg} \mathrm{g}^{-1}, 321.25 \mu \mathrm{g} \mathrm{g}^{-1}, 0.06 \mathrm{mg} \mathrm{g}^{-1}$, $0.03 \mathrm{mg} \mathrm{g}^{-1}$, and $0.44 \mathrm{mg} \mathrm{g}^{-1}$ for $\mathrm{N}, \mathrm{P}, \mathrm{K}, \mathrm{Mg}$ and $\mathrm{Ca}$ between 0 and $10 \mathrm{~cm}$, respectively. Corresponding concentrations between 10 and $20 \mathrm{~cm}$, and 20 and $30 \mathrm{~cm}$ were 0.80 and $0.52 \mathrm{mg} \mathrm{g}^{-1}, 328.77$ and $276.26 \mu \mathrm{g} \mathrm{g}^{-1}$, 0.04 and $0.02 \mathrm{mg} \mathrm{g}^{-1}, 0.03$ and $0.03 \mathrm{mg} \mathrm{g}^{-1}$, and 0.47 and $0.39 \mathrm{mg} \mathrm{g}^{-1}$, respectively.

Table I. ANOVA significance levels ( $P$ values) for bulk density, $\mathrm{pH}$ and nutrients of the soil at three depths.

Soil depth $(\mathrm{cm})$

\begin{tabular}{lccc} 
Character & $0-10$ & $10-20$ & $20-30$ \\
\hline Bulk density & 0.557 & 0.412 & 0.935 \\
pH & 0.138 & 0.502 & 0.074 \\
Nitrogen & 0.872 & 0.892 & 0.646 \\
Phosphorus & 0.971 & 0.276 & 0.807 \\
Potassium & 0.849 & 0.201 & 0.442 \\
Magnesium & 0.970 & 0.065 & 0.283 \\
Calcium & 0.994 & 0.826 & 0.281 \\
\hline
\end{tabular}

\subsection{Stem development}

Cumulative growth in RCD and height for both main and secondary stems increased with age for all spacings (figure 1). Not only was the age effect significant, but was also the interaction age $\times$ spacing (table II), which indicates that the magnitude of the response to competition increased significantly with age. This is particularly evident for RCD of the main stems, as the contrast between the $0.5 \mathrm{~m}$ spacing and the $1.0 \mathrm{~m}$ and $1.5 \mathrm{~m}$ spacings was significant for every age; differences between both groups of spacings in the first, second and third growing seasons differed significantly from the difference in the fourth growing season. This can be seen in figure 1. While the three spacings had very close values in $\mathrm{RCD}$ in the first growing season, differences among spacings accentuated with age such that the stems within the closest spacing reached about half the diameter of those within the $1.5 \mathrm{~m}$ spacing. For RCD of secondary stems, contrasts I and II were significant only in the first growing season. The differences between the $0.5 \mathrm{~m} \mathrm{spac}$ ing and the $1.0 \mathrm{~m}$ and $1.5 \mathrm{~m}$ spacings and between the $1.0 \mathrm{~m}$ and $1.5 \mathrm{~m}$ spacings relative to those in the fourth growing season did not change significantly with age after the first growing season. This pattern probably resulted from the fact that competition had not taken place in the first growing season, as RCD for the three spacings was very close in the first growing season. Differences in height growth among spacings were relatively less pronounced than differences obtained for $\mathrm{RCD}$. For the main stems, contrast I was significant in the second growing season and contrast II was significant in the first growing season only, and none of the contrasts was significant for the secondary stems (table II).

Relative growth rate for both RCD and height of main and secondary stems decreased significantly with age and the age $\times$ spacing interactions were significant $($ figure 1 , table II). Contrast I for RCD of the main stems was significant for the period from the second to the third growing season and contrast II was significant for the period from the first to the second growing season. For contrast I, this can probably be explained by the fact that RGRs for the three spacings were more or less regularly spaced for the period from the first to the second growing season relative to the period from the third to the fourth growing season, and then RGR of the $1.0 \mathrm{~m}$ and $1.5 \mathrm{~m}$ spacings became relatively close for the two other periods. This also explains why contrast II was significant for the period from the first to the second growing season. For RCD RGR of secondary stems, only contrast I was significant, which was probably due to the fact that RGRs for the 1.0 and $1.5 \mathrm{~m}$ spacings were nearly equal for the periods from the second to the third growing season and from the third to the fourth growing 

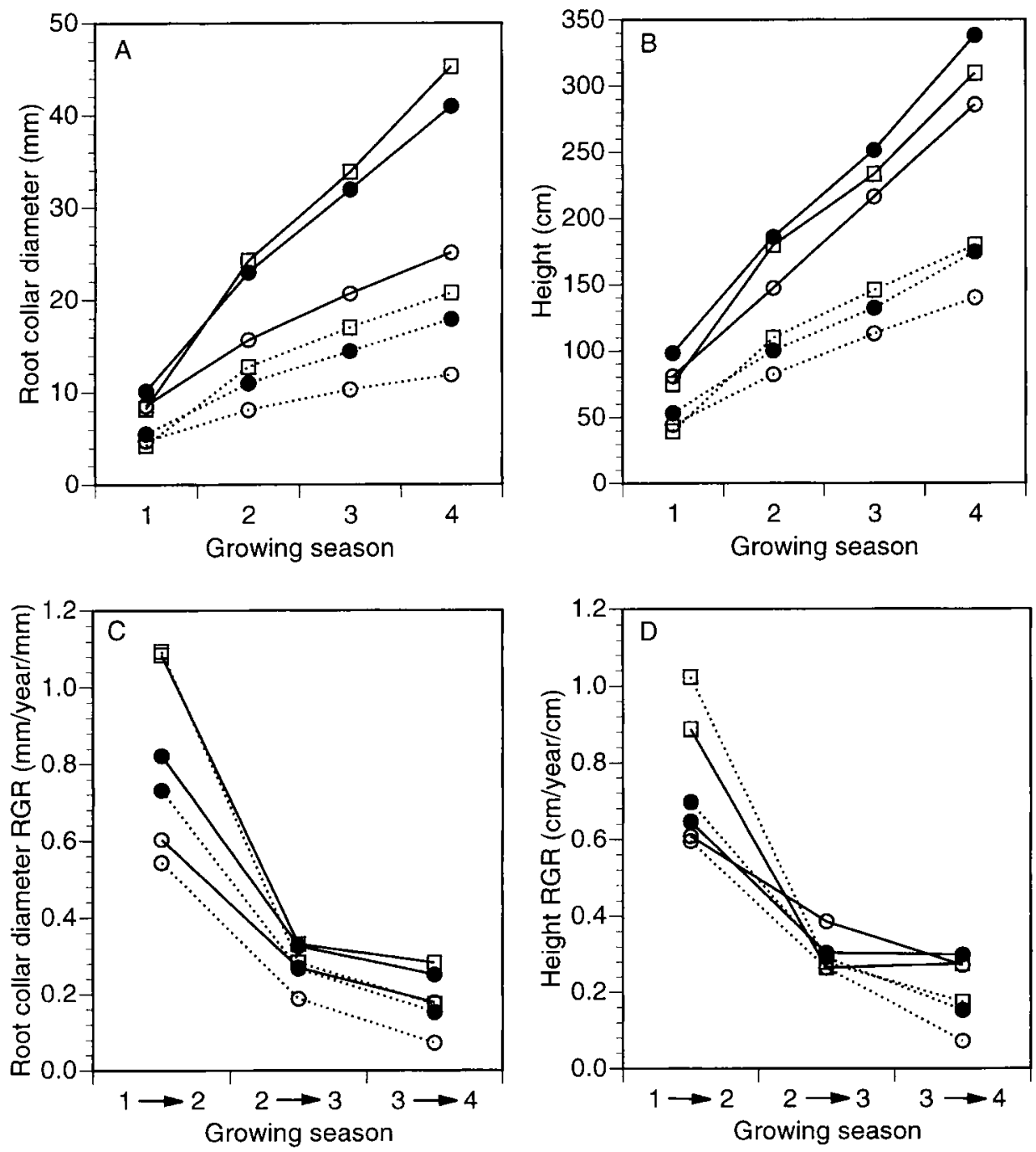

Figure 1. Mean cumulative growth and relative growth rate values for main and secondary stems obtained from individual tree measurements conducted during each growing season. (A) Root collar diameter; (B) Height; (C) RGR for root collar diameter; (D) RGR for height. (O: 0.5 $\mathrm{m}$ spacing; $1.0 \mathrm{~m}$ spacing; $\square: 1.5 \mathrm{~m}$ spacing; —: main stems; $\cdots \cdots \cdot$ : secondary stems).

season, while the $0.5 \mathrm{~m}$ spacing remained relatively lower at each period. For height RGR of main stems, contrast I was significant for the period from the second to the third growing season and contrast II was significant for the period from the first to the second growing season. These trends can be explained by changes in height RGR with age (figure 1). For the period from the first to the second growing season, the $1.5 \mathrm{~m}$ spacing had relatively higher RGR than the other spacings. Then, RGR decreased for all spacings, but the decrease was less pronounced for the 0.5 and $1.0 \mathrm{~m}$ spacings. Finally, height RGR for all spacings did not change much for the two subsequent periods, except for the $0.5 \mathrm{~m}$ spacing, and the three spacings had nearly equal values for the last period. For height RGR of secondary stems, only contrast I was significant (table II). Except in the period from the first to the second growing season, the two largest spacings had nearly equal RGR, while the $0.5 \mathrm{~m}$ spacing had relatively lower RGR.

Stem biomass production for the fourth growing season was estimated for each spacing by using an equation which was derived from dry weight measurements undertaken on harvested trees:

$$
\begin{gathered}
\text { Stem mass }(\mathrm{gr})=0.001332 \times \mathrm{RCD}^{2}(\mathrm{~mm}) \\
\times \text { height }(\mathrm{cm}) \\
\left(\mathrm{R}^{2}=0.99, \mathrm{SE}_{\mathrm{E}}=86.78507\right) .
\end{gathered}
$$

The dry weights computed for individual trees were summed for each sample plot to obtain estimates of biomass production per unit area (table III). For each spacing, the biomass production of secondary stems was on 
Table II. ANOVA significance levels ( $P$ values) for growth data of the main (MS) and secondary stems (SS).

\begin{tabular}{|c|c|c|c|c|c|c|c|c|}
\hline \multirow{2}{*}{$\begin{array}{l}\text { Source of } \\
\text { Variation }\end{array}$} & \multicolumn{2}{|c|}{$\mathrm{RCD}$} & \multicolumn{2}{|c|}{ Height } & \multicolumn{2}{|c|}{ RCD RGR } & \multicolumn{2}{|c|}{ Height RGR } \\
\hline & MS & SS & MS & SS & MS & SS & $\mathrm{MS}$ & SS \\
\hline age & $<0.01$ & $<0.01$ & $<0.01$ & $<0.01$ & $<0.01$ & $<0.01$ & $<0.01$ & $<0.01$ \\
\hline Age $\times$ spacing & $<0.01$ & $<0.0 \mathrm{I}$ & $<0.01$ & $<0.01$ & $<0.01$ & $<0.01$ & $<0.01$ & $<0.01$ \\
\hline \multicolumn{9}{|c|}{ Contrast I: } \\
\hline \multicolumn{9}{|c|}{$0.5 m=1.0 m+1.5 m$} \\
\hline G.S. $2(1 \rightarrow 2)^{\mathrm{b}}$ & $<0.01$ & 0.127 & 0.053 & 0.846 & 0.339 & 0.034 & 0.190 & $<0.01$ \\
\hline G.S. $3(2 \rightarrow 3)$ & $<0.01$ & 0.134 & 0.681 & 0.556 & 0.041 & 0.017 & $<0.01$ & $<0.01$ \\
\hline \multicolumn{9}{|l|}{$\begin{array}{l}\text { Contrast II: } \\
10 \mathrm{~m}=1.5 \mathrm{~m}\end{array}$} \\
\hline G.S. 1 & $<0.01$ & 0.021 & 0.019 & 0.062 & - & - & - & - \\
\hline G.S. $2(1 \rightarrow 2)$ & 0.222 & 0.972 & 0.266 & 0.388 & 0.012 & 0.089 & 0.020 & 0.099 \\
\hline G.S. $3(2 \rightarrow 3)$ & 0.118 & 0.702 & 0.675 & 0.231 & 0.302 & 0.655 & 0.615 & 0.431 \\
\hline
\end{tabular}

a Growing season (G.S.) for RCD and height.

${ }^{b}$ Numbers within brackets indicate the consecutive growing seasons for the contrasts computed for RCD RGR and height RGR.

Table III. Stem Biomass production $\left(\mathrm{kg} \mathrm{ha}^{-1}\right)$ obtained at the end of the fourth growing season within each spacing for both main and secondary stems.

\begin{tabular}{lccc}
\hline & \multicolumn{3}{c}{ Spacing $(\mathrm{m})$} \\
& 0.5 & 1.0 & 1.5 \\
\hline Main stems & 12694 & 7486 & 6189 \\
Secondary stems & 1693 & 902 & 933 \\
Total & 14387 & 8388 & 7122 \\
\hline
\end{tabular}

average $13 \%$ of the production of the main stems. While biomass production did not increase much by decreasing spacing from 1.5 to $1.0 \mathrm{~m}$, biomass production nearly doubled from the $1.0 \mathrm{~m}$ to the $0.5 \mathrm{~m}$ spacing.

\subsection{Crown development}

After four growing seasons, crown width, leaf biomass and leaf area of individual trees differed significantly among spacings (figure $2 A-C$, table $I V$ ). For the main stems, crown width increased on average by a factor of 2 from the $0.5 \mathrm{~m}$ to the $1.0 \mathrm{~m}$ spacing, and by a factor of 1.5 from the $1.0 \mathrm{~m}$ to the $1.5 \mathrm{~m}$ spacing. The corresponding factors for both leaf biomass and leaf area were about 4.2 and 1.7, respectively. Changes for secondary stems were less pronounced. Crown width increased by a factor of 2 from the $0.5 \mathrm{~m}$ to the $1.0 \mathrm{~m}$ spacing, but no significant difference was obtained between the $1.0 \mathrm{~m}$ and $1.5 \mathrm{~m}$ spacings. Leaf biomass and leaf area did not differ significantly among spacings (table IV). For each spacing, differences in leaf biomass and area between main and secondary stems were more pronounced than differences in crown width. Crown width increased by factors of $1.38,1.49$ and 1.15 from secondary to main stems in the $0.5,1.0$ and $1.5 \mathrm{~m}$ spacings, respectively. Corresponding factors for leaf biomass and area were about 3,9 and 6 .

Among all the relative measures of crown development, a significant difference was obtained for crown ratio, and only between the $0.5 \mathrm{~m}$ spacing and the 1.0 and $1.5 \mathrm{~m}$ spacings for both main and secondary stems (figure $2 D-G$, table IV). Compared with main stems, secondary stems had greater CSR, but lower LAP and nearly equal LAR.

Significant decreases in SLA were obtained between the $0.5 \mathrm{~m}$ spacing and the 1.0 and $1.5 \mathrm{~m}$ spacings for the main stems within the three sections (figure 3 , table $I V$ ). The 1.0 and $1.5 \mathrm{~m}$ spacings did not differ significantly, except for section 2. For secondary stems, the ANOVA was computed only for section 1 of the crown, which also indicated a significant decrease in SLA with increase in spacing between the $0.5 \mathrm{~m}$ spacing and the 1.0 and $1.5 \mathrm{~m}$ spacings (figure 3 ). Specific leaf area values were missing for some plots in sections 2 and 3, as several secondary stems had very small crowns. Despite the absence of statistical tests, the same pattern of decrease with increase in spacing was obtained (figure 3 ). For both main and secondary stems, SLA decreased from the bottom to the top of the crown. 

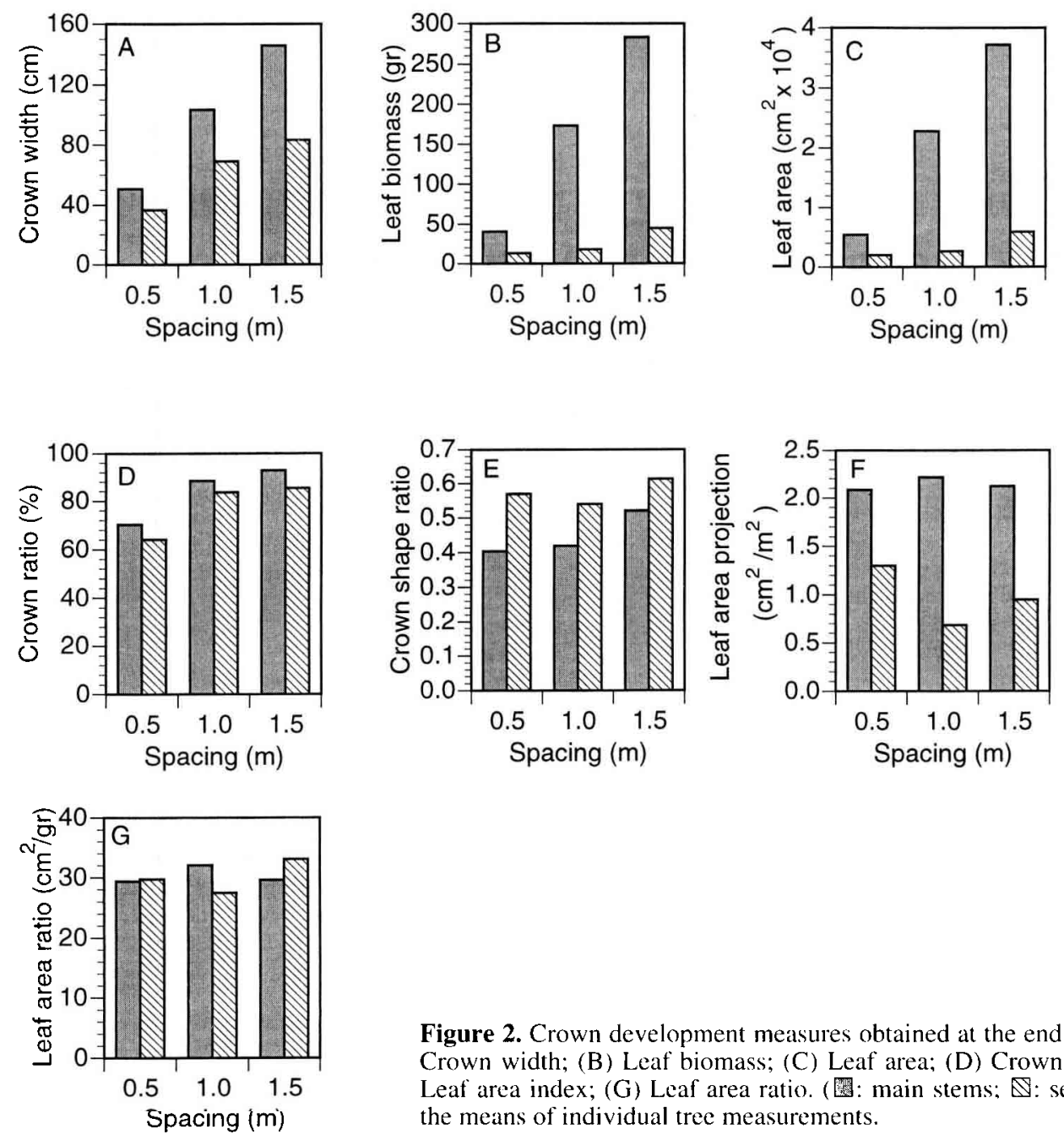

Figure 2. Crown development measures obtained at the end of the fourth growing season. (A) Crown width; (B) Leaf biomass; (C) Leaf area; (D) Crown ratio; (E) Crown shape ratio; (F) Leaf area index; (G) Leaf area ratio. (圈: main stems: $\mathbb{Q}$ : secondary stems). Values represent the means of individual tree measurements.

Leaf area index, which was computed from the summation of the leaf area of individual trees within a sample plot divided by the area upon which they stood, differed significantly only between the $0.5 \mathrm{~m}$ spacing and the $1.0 \mathrm{~m}$ and the $1.5 \mathrm{~m}$ spacings for both main and secondary stems (table IV). Average values for the main stems were $3.11,2.51$ and 2.46 for the $0.5,1.0$ and $1.5 \mathrm{~m}$ spacings, respectively. Corresponding values for secondary stems were $0.56,0.33$ and 0.38 .

\subsection{Nutrients}

Spacing did not have a major effect on nutrient concentrations (figure 4 , table $V$ ). No significant differences were obtained within section 1 for all nutrients. Significant differences were obtained for phosphorus in sections 2 and 3 of the crown, and for potassium in section 2 only. For stems, significant differences were obtained for $\mathrm{N}, \mathrm{P}$ and $\mathrm{Ca}$.

Linear regression equations of SLA as a function of tree nutrient concentrations were significant, except for $\mathrm{N}$ and $\mathrm{P}$ in the $0.5 \mathrm{~m}$ spacing and for $\mathrm{Mg}$ in the $1.5 \mathrm{~m}$ spacing (table $V I$ ). The strength of the relationship improved for $\mathrm{N}, \mathrm{P}$ and $\mathrm{K}$ from the $0.5 \mathrm{~m}$ spacing to the $1.0 \mathrm{~m}$ spacing, remained the same for $\mathrm{Ca}$, and decreased for $\mathrm{Mg}$. For each nutrient, the large confidence limits of the slopes do not indicate significant differences among the spacings. 


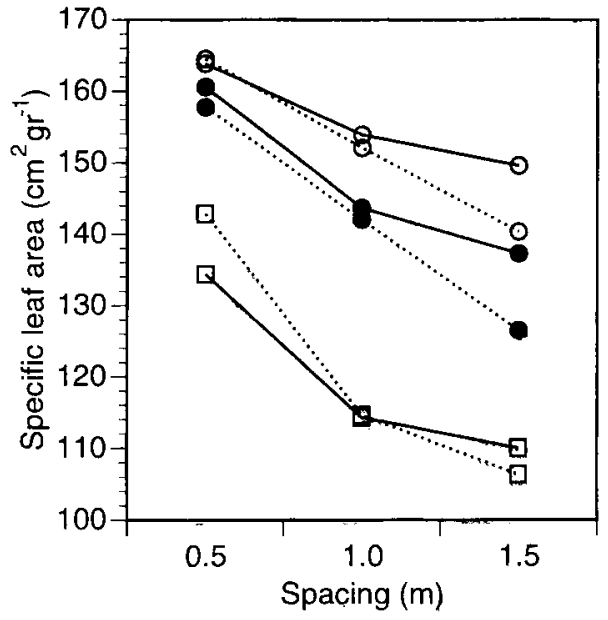

Figure 3. Average specific leaf areas for different sections of the crown and for main and secondary stems obtained at the end of the fourth growing season. ( $\bigcirc$ : Section 1; O: Section 2; $\square$ : Section 3 ; —: main stems; …... secondary stems).

\section{Discussion}

\subsection{Site conditions and growth}

The absence of significant differences for bulk density, $\mathrm{pH}$ and nutrient concentrations at all depths indicates that trees were growing in homogeneous soil conditions (table I). Thus, the significant variations in growth, crown development and nutrient contents in leaves and stems that were obtained cannot be attributed to differences in soil conditions.

When spacings were compared one by one, secondary stems reached about half the size of the main stems in every year (figure 1). While both groups had relatively close RGRs initially, differences accentuated with age. Internal competition for carbohydrates within a plant probably explains these results [28]. This theory stipulates that carbohydrate partitioning is influenced by competitive interactions among internal organs or sinks. As they emerged first, main stems gained a competitive advantage by building up larger crowns with more foliage than secondary stems, allowing them to become strong sinks. The increase in differences in cumulative growth between main and secondary stems suggests that the amplitude of competitive advantage that the main stems gained initially increased with age. This is also supported by changes in RGR. Despite lower initial cumulative RCD and height, the capacity of secondary stems to produce biomass was nearly equal to that of main stems in the first growing season, particularly for the 0.5 and $1.5 \mathrm{~m}$ spacings for RCD and the 0.5 and $1.0 \mathrm{~m}$ spacings for height. Then, the capacity of secondary stems to produce biomass decreased relative to that of main stems.

The pattern of decrease in RGR with age for both main and secondary stems indicates that the capacity of trees to produce biomass diminished (figure l), which is the usual trend of change in efficiency for perennial plants [53]. However, when spacings are compared, differences in cumulative growth increased significantly with age while differences in RGR decreased, particular-

Table IV. ANOVA significance levels ( $P$ values) for the different measures of crown development of the main (MS) and secondary stems (SS) with spacing as the source of variation.

Orthogonal contrast

\begin{tabular}{|c|c|c|c|c|c|c|}
\hline \multirow[b]{2}{*}{ Character } & \multirow[b]{2}{*}{ MS } & \multirow[b]{2}{*}{ SS } & \multicolumn{2}{|c|}{$0.5 \mathrm{~m}=1.0+1.5 \mathrm{~m}$} & \multicolumn{2}{|c|}{$1.0 \mathrm{~m}=1.5 \mathrm{~m}$} \\
\hline & & & MS & SS & MS & SS \\
\hline Crown width & $<0.01$ & 0.033 & $<0.01$ & 0.013 & $<0.01$ & 0.466 \\
\hline Leaf biomass & $<0.01$ & 0.417 & $<0.01$ & - & 0.033 & - \\
\hline Leaf area & $<0.01$ & 0.447 & $<0.01$ & - & 0.033 & - \\
\hline Crown ratio & $<0.01$ & $<0.01$ & $<0.01$ & $<0.01$ & 0.166 & 0.686 \\
\hline Crown shape ratio & 0.112 & 0.914 & - & - & - & - \\
\hline Leaf area projection & 0.865 & 0.270 & _- & - & _- & - \\
\hline Leaf area ratio & 0.609 & 0.541 & - & - & _- & - \\
\hline \multicolumn{7}{|l|}{ Specific leaf area } \\
\hline Section 1 & 0.029 & 0.020 & 0.013 & 0.010 & 0.305 & 0.081 \\
\hline Section 2 & $<0.01$ & - & $<0.01$ & - & 0.035 & - \\
\hline Section 3 & $<0.01$ & - & $<0.01$ & - & 0.203 & - \\
\hline Leaf area index & 0.024 & 0.050 & 0.029 & 0.014 & 0.548 & 0.389 \\
\hline
\end{tabular}



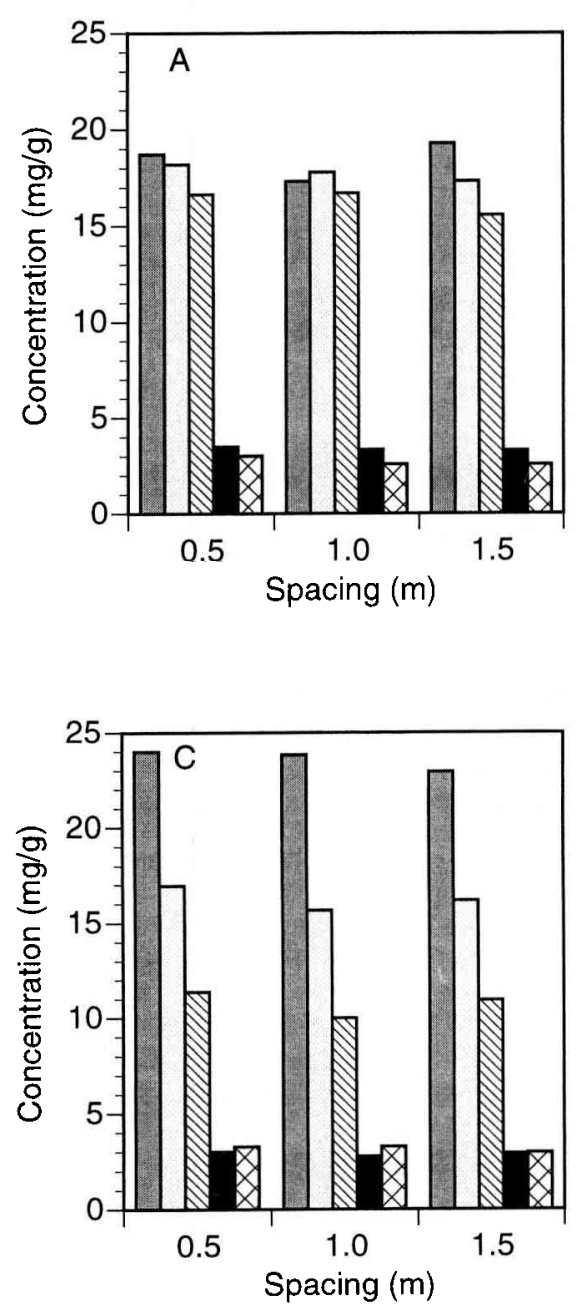
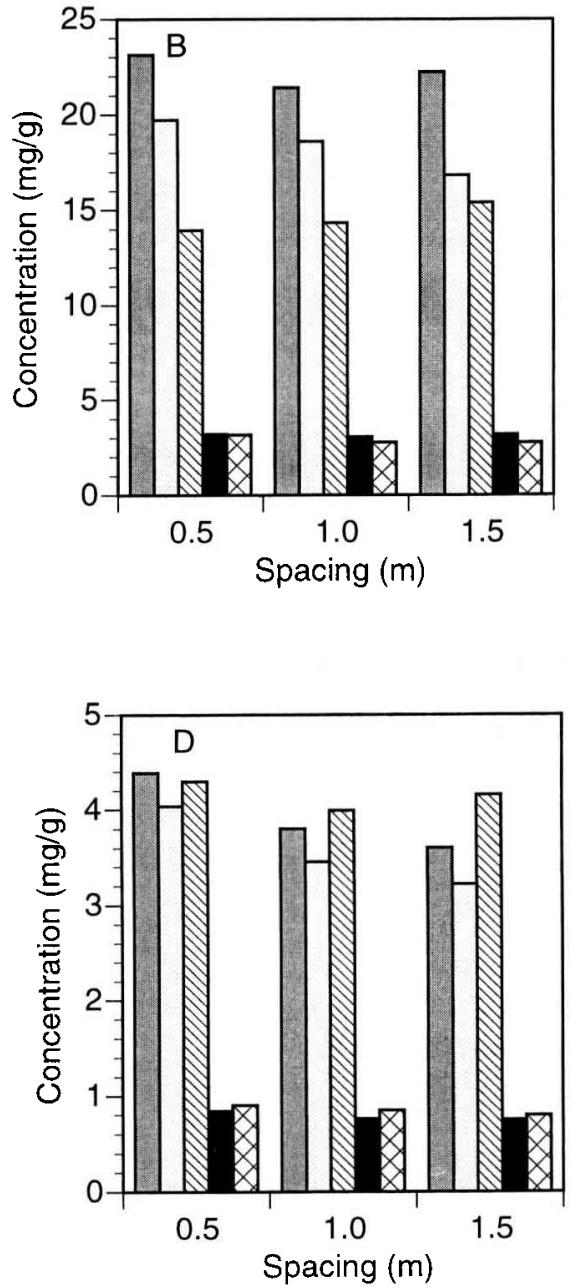

Figure 4. Mean nutrient contents for the leaves of the three sections of the crown and the stem obtained at the end of the fourth growing season. (A) Section 1; (B) Section 2; (C) Section 3; (D) Stems (圆: N; ]: K; $\mathbb{B}: \mathrm{Ca} ; \mathbf{\square}$ : $\mathrm{Mg} ; \mathrm{X}: \mathrm{P})$. ly for RCD (figure 1). Thus, the increase in cumulative growth from the $0.5 \mathrm{~m}$ to the $1.5 \mathrm{~m}$ spacing did not result in a proportional decrease in the capacity of plants to produce biomass, which suggests an acclimation to competitive stress.

\subsection{Crown development}

The significant differences obtained for crown width and leaf biomass and area for the main stems indicate that competition reduced the aerial space occupancy of individual crowns and that the amount of foliage they supported as spacing was decreased. Crowns did not overlap much since widths attained coincided closely with initial spacings. For secondary stems, the effect of competition was less pronounced as only crown width differed significantly (table $I V$ ). The internal competition for carbohydrates, which was discussed above, probably explains this pattern: as the main stems became strong sinks, fewer resources were available for the development of crowns of secondary stems.

Despite the reduction in available growing space, the efficiency of crowns to occupy their growing space was not greatly affected. No significant differences were obtained for CSR, LAI and LAR, which indicates that the ability of crowns to intercept solar radiation, the amount of leaf cover and the proportion of photosynthesizing tissues relative to respiring biomass did not vary with the intensity of competitive stress. Even though significant differences were obtained for both main and secondary stems, the lower $\mathrm{CR}$ in the $0.5 \mathrm{~m}$ spacing relative to the 1.0 and $1.5 \mathrm{~m}$ spacings does not indicate severe crown recession, which indicates that, even though the 
Table V. Anova significance levels ( $P$ values) for nutrients within the different sections of the crown and the stems.

\begin{tabular}{|c|c|c|c|c|c|}
\hline $\begin{array}{l}\text { Source of } \\
\text { variation }\end{array}$ & $\mathrm{N}$ & $\mathrm{P}$ & K & $\mathrm{Mg}$ & $\mathrm{Ca}$ \\
\hline \multicolumn{6}{|c|}{ Section 1} \\
\hline Spacing & 0.254 & 0.058 & 0.559 & 0.139 & 0.299 \\
\hline \multicolumn{6}{|c|}{ Section 2} \\
\hline Spacing & 0.324 & $<0.01$ & $<0.01$ & 0.309 & 0.136 \\
\hline \multicolumn{6}{|c|}{ Orthogonal contrast } \\
\hline $0.5 \mathrm{~m}=1.0+1.5 \mathrm{~m}$ & - & $<0.01$ & $<0.01$ & - & - \\
\hline $1.0 \mathrm{~m}=1.5 \mathrm{~m}$ & - & 0.825 & $<0.01$ & - & - \\
\hline \multicolumn{6}{|c|}{ Section 3} \\
\hline Spacing & 0.682 & 0.016 & 0.389 & 0.120 & 0.071 \\
\hline \multicolumn{6}{|c|}{ Orthogonal contrast } \\
\hline $0.5 \mathrm{~m}=1.0+1.5 \mathrm{~m}$ & - & 0.082 & - & - & - \\
\hline $1.0 \mathrm{~m}=1.5 \mathrm{~m}$ & - & 0.010 & - & - & - \\
\hline \multicolumn{6}{|c|}{ Stems } \\
\hline Spacing & $<0.01$ & 0.197 & $<0.01$ & 0.032 & 0.244 \\
\hline \multicolumn{6}{|c|}{ Orthogonal contrast } \\
\hline $0.5 \mathrm{~m}=1.0+1.5 \mathrm{~m}$ & $<0.01$ & - & $<0.01$ & 0.012 & - \\
\hline $1.0 \mathrm{~m}=1.5 \mathrm{~m}$ & 0.220 & - & 0.172 & 0.732 & - \\
\hline
\end{tabular}

expansion of individual crowns was severely inhibited by neighboring competitors, leaves located deep within the canopy were able to photosynthesize under relatively low light intensity.
The significant changes in SLA in the three crown sections and the increase with crown depth indicate acclimation to shade conditions $[11,20,50]$ as crown closure occurred and intensified. The pattern of change in SLA with increase in stand density is similar to that observed in plants growing under different light conditions $[11,19,35,38]$, in plants subjected to competition by surrounding vegetation $[3,4,52]$ or in trees released following thinning [e.g. 20]. Increase in SLA with crown depth was observed by Hager and Sterba [20] in Norway spruce (Picea abies (L.) Karst.) stands and by Petersen et al. [40] in Fraxinus mandshurica stands. Similarly to the results of this study, Petersen et al. [40] observed that the increase in SLA with crown depth accentuated with stand density. Changes in SLA are often related to sun and shade leaf morphology with anatomical and physiological characteristics adapted to photosynthesize efficiently under high and low solar radiation levels, respectively. For instance, sun leaves have lower SLA, thicker mesophyll, greater stomatal density and size, and larger chloroplasts than shade leaves [17]. According to Ducrey [11], when SLA is increased, light rays can reach carboxylation sites more easily and resistance to $\mathrm{CO}_{2}$ diffusion within the mesophyll and maintenance respiration needs are reduced. Chen et al. [6] related the increase in SLA to improvement in the capacity of leaves to intercept light. Therefore, the morphological acclimation of leaves to shade conditions, as observed in this study, probably explains why the efficiency of crowns to occu-

Table VI. Linear regression analyses for specific leaf area with tree nutrient concentration as independent variables.

\begin{tabular}{|c|c|c|c|c|c|}
\hline Nutrient & Intercept & Slope ${ }^{a}$ & $\mathrm{r}^{2}$ & $F$ & $\mathrm{P}$ \\
\hline \multicolumn{6}{|l|}{ Spacing: $0.5 \mathrm{~m}$} \\
\hline $\mathrm{N}$ & 150.867 & $-0.114 \pm 1.524 n^{b}$ & 0.00 & 0.02 & 0.881 \\
\hline $\mathrm{K}$ & 94.0823 & $3.016 \pm 1.961$ & 0.16 & 9.53 & 0.003 \\
\hline $\mathrm{Ca}$ & 83.469 & $4.858 \pm 1.801$ & 0.36 & 29.31 & $<0.01$ \\
\hline $\mathrm{Mg}$ & 70.109 & $24.936 \pm 12.319$ & 0.24 & 16.51 & $<0.01$ \\
\hline $\mathrm{P}$ & 94.989 & $13.302 \pm 9.567$ & 0.31 & 8.47 & $<0.01$ \\
\hline $\mathrm{K}$ & 76.992 & $3.243 \pm 1.863$ & 0.41 & 1.3 .28 & $<0.01$ \\
\hline $\mathrm{Ca}$ & 86.269 & $3.629 \pm 2.792$ & 0.28 & 7.40 & 0.013 \\
\hline $\mathrm{Mg}$ & 86.541 & $15.921 \pm 16.157$ & 0.18 & 4.25 & 0.053 \\
\hline $\mathrm{Ca}$ & 91.245 & $2.821 \pm 2.239$ & 0.32 & 7.213 & 0.017 \\
\hline $\mathrm{Mg}$ & 134.387 & $-0.977 \pm 13.467 n$ & 0.00 & 0.023 & 0.879 \\
\hline
\end{tabular}

${ }^{a}$ With confidence limits $(P=0.05)$.

$\mathrm{b}_{\mathrm{n}}$ : indicates a non-significant test $(P<0.05)$ that the coefficient is different from zero or that $\mathrm{F}$ value is significant. 
py their growing space was not affected significantly by the intensity of competition.

\subsection{Nutrients}

Except for $\mathrm{Ca}$, foliar nutrient concentrations for the three crown sections were close or even superior to the critical levels reported by Bernier [2] for Populus deltoides, which were $20,13,22,1.8$ and $1.7 \mathrm{mg} \mathrm{g}^{-1}$ for $\mathrm{N}$, $\mathrm{K}, \mathrm{Ca}, \mathrm{Mg}$ and $\mathrm{P}$, respectively. However, comparing foliar data with other studies must be done with caution because nutrient contents are affected by several factors such as time of the season or position in the crown [29] or clone type [2]. Thus, the values reported by Bernier [2] must be considered as a gross indicator that competition for nutrients was not important in any of the spacings. Even though concentration of $\mathrm{Ca}$ was much lower than the critical level reported by Bernier [2], no significant differences were obtained (table $V$ ). The significant differences obtained for $\mathrm{P}$ in sections 2 and 3 and for $\mathrm{K}$ in section 2 do not suggest competition for nutrients either. In fact, the relatively lower nutrient concentrations in the $1.5 \mathrm{~m}$ spacing relative to the 0.5 or $1.0 \mathrm{~m}$ spacings and in the $1.0 \mathrm{~m}$ spacing relative to the $1.5 \mathrm{~m}$ spacing probably resulted from dilution effects associated with increase in biomass $[12,36,43,48]$. For nutrient concentration in stems, significant differences were obtained between the $0.5 \mathrm{~m}$ spacing and the 1.0 and 1.5 $\mathrm{m}$ spacings for $\mathrm{N}, \mathrm{K}$ and $\mathrm{Mg}$. Similarly to foliar concentrations, these differences are relatively small in absolute values, and the pattern of increase with decrease in spacing was obtained, also suggesting a dilution effect.

For each nutrient, the relatively large overlaps between the confidence limits of the slopes of the relationships between SLA and tree nutrient concentration, suggesting that the slopes did not differ significantly among spacings, indicate that synergistic interaction of leaf nutrition and leaf acclimation did not take place: nutrient use efficiency of individual trees was not affected by competition. These results provide another indication that competition for nutrients was not important. The same relationship derived in other studies, but with nitrogen only, resulted in stronger linear relationships [e.g. 34, 35, 42]. However, these trees were growing under controlled conditions without competition and with different rates of fertilizer applications or in the field on sites characterized by different fertility levels. Large variations in tree nutrient concentrations were observed, which made it possible to highlight the strong dependence of SLA on nutrient content. In the present study, relatively small variation in nutrient content of individual trees within each spacing existed, in addition to the absence of differences among spacings. Thus, variation in SLA resulted principally from variation in light conditions as crown closure occurred and intensified.

\section{Conclusions}

The culture of hybrid poplar plantations on short rotation has accelerated considerably in the last two decades in North America and Europe. Several forest product corporations which used to harvest natural forests exclusively for the production of pulp, paper and logs are now investing considerably in hybrid poplar plantations. The economic reality of these corporations requires that their foresters base their decisions on sound and adequate biological information to ensure that biomass production is maximized at the lowest possible cost. This goal can be achieved by 1) selecting the appropriate hybrid for a given site, 2) increasing biomass production per unit area, 3) shortening the rotation as much as possible, and 4) improving site fertility by irrigation and/or application of fertilizers or residues from sewage systems. In particular, options 2 and 3 are closely related: the shorter the rotation, the closer the spacing must be to increase the economic viability of intensively managed cultures. While much research has been devoted to the comparison of the productivity of many hybrids on various sites and to the effect of modifying site fertility, less attention has been given to the study of productivity in the light of competition, which may help to determine an optimal spacing and reduce the rotation.

This investigation has shown that competition takes place quite rapidly in hybrid poplar DN-74 stands, particularly in the closest spacing. Even though the intensity of competition increased dramatically as spacing was decreased, our results indicate that competition occurred only at the crown level: it resulted in diminishing the aerial space occupancy of crowns, but was not intense enough to cause a significant decrease in their efficiency to occupy their growing space, in the uptake rate of nutrients and in nutrient use efficiency (which suggests that cultural treatments aiming at improving site fertility might be useless on this type of soil). In addition, the morphological characteristics of the foliage changed substantially to acclimate to reduced light conditions. These factors probably explain why this hybrid maintained a relatively high capacity to produce biomass per unit area in the closest spacing. They also suggest that the increase in competition that would have taken place if the rotation had been 2 or 3 years longer might not have resulted in significant negative effect on productivity per unit area. Despite the fact that individual tree size decreased by a two-fold factor from the $1.0 \mathrm{~m}$ to the $0.5 \mathrm{~m}$ spacing, stem 
biomass production per unit area nearly doubled. In fact, the drastic changes observed between these two spacings indicate that a relatively small change in initial spacing may result in substantial differences in biomass production per unit area. For instance, even a $0.75 \mathrm{~m}$ spacing would result in substantially greater biomass production per unit area than a $1.0 \mathrm{~m}$ spacing.

Acknowledgements: The assistance of Drs J. Baldock, E. Turcotte, F. McBain, L. Clark, B. Frederick and R. Miller, formerly of the Petawawa National Forestry Institute, with field work and laboratory analyses is greatly appreciated. Sincere thanks are also extended to Dr G. Robitaille, Dr F. Bigras and Ms M. BernierCardou, of the Laurentian Forestry Centre, for helpful comments in the review of the manuscript and advice on statistical analyses.

\section{References}

[1] Abrams M.D., Kubiske M.E., Leaf structural characteristics of 31 hardwood and conifer tree species in central Wisconsin: influence of light regime and shade-tolerance rank, For. Ecol. Manage. 31 (1990) 245-253.

[2] Bernier B., Nutrient cycling in Populus: a literature review with implications in intensively-managed plantations, Canadian Forestry Service, ENFOR Report No. 6, 1984.

[3] Brand D.G., The establishment of boreal and sub-boreal conifer plantations: an integrated analysis of environmental conditions and seedling growth, For. Sci. 37 (1991) 68-100.

[4] Burton P.J., Bazzaz F.A., Ecophysiological responses of tree seedlings invading different patches of old-field vegetation, J. Ecol. 83 (1995) 99-112.

[5] Ceulemans R., Scarascia-Mugnozza G., Wiard B.M., Braatne J.H., Hinckley T.M., Stettler R.F., Isebrands J.G., Heilman P.E., Production physiology and morphology of Populus species and their hybrids grown under short rotation. I. Clonal comparisons of 4-year growth and phenology, Can. J. For. Res. 22 (1992) 1937-1948.

[6] Chen H.Y.H., Klinka K., Kayahara G.J., Effects of light on growth, crown architecture, and specific leaf area for naturally established Pinus contorta var. latifolia and Pseudotsuga menziesii var. glauca saplings, Can. J. For. Res. 26 (1996) $1149-1157$.

[7] Czapowskyj M.M., Safford L.O., Site preparation, fertilization and 10-year yields of hybrid poplar on a clear-cut forest site in eastern Maine, USA, New For. 7 (1993) 331-344.

[8] DeBell D.S., Harrington C.A., Productivity of Populus in monoclonal and polyclonal blocks at three spacings, Can. J. For. Res. 27 (1997) 978-985.

[9] DeBell D.S., Harrington C.A., Clendenen G.W., Zasda J.C., Tree growth and stand development of four Populus clones in large monoclonal plots, New For. 14 (1997) 1-18.

[10] Dijkstra P., Cause and effect of differences in specific leaf area, in: Lambers H., Cambridge M.L., Konings H., Pons
T.L. (Eds.) Causes and Consequences of Variation in Growth Rate and Productivity of Higher Plants, SPB Academic Publishing bv, The Hague, The Netherlands, 1989, pp. 125-140.

[11] Ducrey M., Variation in leaf morphology and branching pattern of some tropical rain forest species from Guadeloupe (French West Indies) under semi-controlled light conditions, Ann. Sci. For, 49 (1992) 553-570.

[12] Finér L., Nutrient concentrations in Pinus sylvestris growing on an ombrotrophic pine bog, and the effects of PK and NPK fertilization, Scand. J. For. Res. 7 (1992) 205-218.

[13] Fisons Instruments, Instruction manual NA 2000 nitrogen analyzer, Fisons Instruments, Milan, Italy, 1993.

[14] Fitter A.H., Hay R.K.M., Environmental Physiology of Plants, 2nd ed., Academic Press, London, UK, 1987.

[15] Ford E.D., The control of tree structure and productivity through the interaction of morphological development and physiological processes, Int. J. Plant. Sci. 153 (1992) S147-S162.

[16] Gelhaye D., Ranger J., Bonneau M., Biomasse et minéralomasse d'un taillis à courte révolution du peuplier Beaupré installé sur un sol acide hors vallée, amélioré par fertilisation, Ann. Sci. For. 54 (1997) 649-665.

[17] Givnish T.J., Adaptation to sun and shade: a wholeplant perspective, Aust. J. Plant Physiol. 15 (1988) 63-92.

[18] Goldberg D.E., Components of resource competition in plant communities, in: Grace, J.B., Tilman, D. (Eds.), Perspectives on Plant Competition, Academic Press, Inc., New York, USA, 1990, pp. 27-49.

[19] Gottschalk K.W., Shade, leaf growth and crown development of Quercus rubra, Quercus velutina, Prunus serotina and Acer rubrum seedlings, Tree Physiol. 14 (1994) 735-749.

[20] Hager H., Sterba H., Specific leaf area and needle weight of Norway spruce (Picea abies) in stands of different densities, Can. J. For. Res. 15 (1985) 389-392.

[21] Hambly S., The growth of hybrid poplar in Nelder spacing trials, in: Barkley B.A., McVey G. (Eds.), Poplar Culture to the Year 2000, Proceedings of the Poplar Councils of the United States and Canada joint meeting. College of Environmental Science and Forestry, Syracuse, NY, USA, 1987, pp. 63-73.

[22] Heckrodt W.F., Close spaced short rotation poplar production using paper mill sludge as mulch, in: Barkley B.A., McVey G. (Eds.), Poplar Culture to the Year 2000, Proceedings of the Poplar Councils of the United States and Canada joint meeting. College of Environmental Science and Forestry, Syracuse, NY, USA, 1987, pp. 85-93.

[23] Heilman P.E., Xie F., Influence of nitrogen on growth and productivity of short-rotation Populus trichocarpa $\times$ Populus deltoides hybrids, Can. J. For. Res. 23 (1993) 1863-1869.

[24] Hunt R., Plant Growth Curves. The Functional Approach to Plant Growth Analysis, Edward Arnold Limited, London, 1982.

[25] Hunt R., Basic Growth Analysis, Unwin Hyman Ltd, London, 1990. 
[26] Kalra Y.P., Maynard D.G., Methods manual for forest soil and plant analysis. Forestry Canada, Northern Forestry Centre, Information Report NOR-X-319, 1991.

[27] Klinka K., Wang Q., Kayahara G.J., Carter R.E., Blackwell B.A., Light-growth response relationships in Pacific silver fir (Abies amabilis) and subalpine fï (Abies lasiocarpa), Can. J. Bot. 70 (1992) 1919-1930.

[28] Kozlowski T.T., Kramer P.J., Pallardy S.G., The Physiological Ecology of Woody Plants, Academic Press, Inc., New York, 1991.

[29] Kramer P.J., Kozlowski T.T., Physiology of Woody Plants, Academic Press, Inc., New York, USA, 1979.

[30] Kuuluvainen T., The effect of two growth forms of Norway spruce on stand development and radiation interception: a model analysis, Trees 5 (1991) 171-179.

[31] Lambers H., Poorter H., Inherent variation in growth rate between higher plants: a search for physiological causes and ecological consequences, Adv. Ecol. Res. 23 (1992) $187-261$.

[32] LI-COR, Inc, LI-3100 area meter instruction manual, LI-COR, Inc., Lincoln NE, Publication No. 7903-20, 1987.

[33] LKB Biochrom Ltd, Ultrospec II instruction manual, LKB Biochrom Ltd, Cambridge, UK, 1985.

[34] McDonald A.J.S., Phenotypic variation in growth rate as affected by $\mathrm{N}$-supply: its effects on net assimilation rate (NAR), leaf weight ratio (LWR) and specific leaf area (SLA), in: Lambers H., Cambridge M.L., Konings H., Pons T.L. (Eds.), Causes and Consequences of Variation in Growth Rate and Productivity of Higher Plants, SPB Academic Publishing bv, The Hague, The Netherlands, 1989, pp. 35-44.

[35] McDonald A.J.S., Lohammar T., Ingestad T., Net assimilation rate and shoot area development in birch (Betula pendula Roth.) at different steady-state values of nutrition and photon flux density, Trees 6 (1992) 1-6.

[36] McKevlin M.R., Hook D.D., McKee W.H. Jr., Growth and nutrient use efficiency of water tupelo seedlings in flooded and well-drained soil, Tree Physiol. 15 (1995) 753-758.

[37] Mehlich A., New extractant for soil test evaluation of phosphorus, potassium, magnesium, calcium, sodium, manganese and zinc, Commun. Soil Sci. Plant Anal. 9 (1978) $477-492$.

[38] Mitchell A.K., Arnott J.T., Effects of shade on the morphology and physiology of amabilis fir and western hemlock seedlings, New For. 10 (1995) 79-98.

[39] Ontario Ministry of Natural Resources, New forests in Eastern Ontario. Hybrid poplar, Ontario Ministry of Natural Resources, Science and Technology Series Vol. 1, 1983.

[40] Petersen T.D., Ning Z., Newton M., Dynamics of size structures in seedling stands of Fraxinus mandshurica in northeast China, Ann. Bot. 66 (1990) 255-263.
[41] Pöykkö V.T., Pulkkinen P.O., Characteristics of normal-crowned and pendula spruce (Picea abies (L.) Karst.) examined with reference to the definition of a crop tree ideotype, Tree Physiol. 7 (1990) 201-207.

[42] Reich P.B., Kloeppel B.D., Ellsworth D.S., Walters M.B., Different photosynthesis-nitrogen relations in deciduous hardwood and evergreen coniferous tree species, Oecologia 104 (1995) 24-30.

[43] Righetti T.L., Wilder K.L., Cummings G.A., Plant analysis as an aid in fertilizing orchards, in: Westerman R.L. (Ed.), Soil Testing and Plant Analysis, 3rd ed., Soil Science Society of America, Inc., Madison, USA, 1990. pp. 563-601.

[44] SAS Institute Inc., SAS/STAT ${ }^{\circledR}$ user's guide, Version 6, 4th ed., Volume 2, SAS Institute Inc., Cary, NC, USA, 1989.

[45] Sprinz P.T., Burkhart H.E., Relationships between tree crown, stem, and stand characteristics in unthinned loblolly pine plantations, Can. J. For. Res. 17 (1987) 534-538.

[46] Strobl S., A decade of clone-site testing in eastern Ontario, in: Barkley B.A., McVey G. (Eds.), Poplar Culture to the Year 2000, Proceedings of the Poplar Councils of the United States and Canada joint meeting. College of Environmental Science and Forestry, Syracuse, NY, USA, 1987, pp. 29-39.

[47] Tucker G.F., Hinckley T.M., Leverenz J.W., Jiang S.M., Adjustments of foliar morphology in the acclimation of understory Pacific silver fir following clearcutting, For. Ecol. Manage. 21 (1987) 249-268.

[48] van den Driessche R., Relationship between spacing and nitrogen fertilization of seedlings in the nursery, seedling mineral nutrition, and outplanting performance, Can. J. For. Res. 14 (1984) 431-436.

[49] Varian, Spectra AA-300/400 operation manual, Varian, Mulgrave, Australia, 1988.

[50] Wang J.R., Simard S.W., Kimmins J.P., Physiological responses of paper birch to thinning in British Columbia, For. Ecol. Manage. 73 (1995) 177-184.

[51] Wang Y.P., Jarvis P.G., Influence of crown structural properties on PAR absorption, photosynthesis, and transpiration in Sitka spruce: application of a model (MAESTRO), Tree Physiol. 7 (1990) 297-316.

[52] White A.S., Elliott K.J., Predicting the effects of hardwood competition on red pine seedling growth, Can. J. For. Res. 22 (1992) 1510-1515.

[53] Zedaker S.M., Burkhart H.E., Stage R.S., General principles and patterns of conifer growth and yield, in: Walstad J.D., Kuch P.J. (Eds.), Forest Vegetation Management for Conifer Production, John Wiley \& Sons, New York, USA, 1987, pp. 203-241. 